FACTA UNIVERSITATIS

Series: Economics and Organization Vol. 16, N 3, 2019, pp. 299 - 314

https://doi.org/10.22190/FUEO1903299Z

Original Scientific Paper

\title{
WHY PAY MORE - WORLD EVIDENCE ON M\&A BID PREMIUM DETERMINANTS
}

\author{
UDC 334.75 \\ 658.14
}

\author{
Milutin Živanović ${ }^{1}$, Nataša Džudović \\ ${ }^{1}$ University of Belgrade Faculty of Economics, Belgrade, Serbia \\ ${ }^{2}$ eFront, Belgrade, Serbia
}

\begin{abstract}
Corporate mergers and acquisitions represent one of the most dynamic fields in the world of business finance. These remarkably complex transactions' success may vary depending on the economic and institutional environments in which the transactions are performed. This paper investigates the information content of the bid premium determined in the M\&A transactions and focuses on the identification of significant differences in its amount depending on: (1) the observed timeframe (width of the event window observed relative to the moment of the transaction announcement); (2) current equity market trends (3) institutional environments and the degree of the economic development of the countries in which the transaction participants operate; and (4) selected payment method and motive for entering the transaction in regard to space and time dimensions of bid premium. Examining the sample of 783 merger and acquisition transactions at the global economy level, the research explores the importance and range of time and space determinants of bid premiums in $M \& A$ transactions.

Our results confirm that bid premium carries significant information and that is highly dependent on the observed timeframe, i.e. we find evidence of information "leakage" prior to transaction announcement and sluggish adaptation to expected value creation due to market characteristics, level of economic development of countries in which M\&As are operated and specific transaction characteristics such as payment method and motive for participating in such transaction. The paper shows that the results can often differ depending on whether the analysis includes dominant trends in the most important capital markets.
\end{abstract}

Key words: mergers, acquisitions, bid premium, market for corporate control, institutional environment, payment method

JEL Classification: G14, G34

Received April 24, 2019 / Revised July 01, 2019 / Accepted July 08, 2019

Corresponding author: Milutin Živanović

University of Belgrade, Faculty of Economics, Kamenička 6, 11000 Belgrade, Serbia

E-mail: milutinzivanovic@ekof.bg.ac.rs

(๑) 2019 by University of Niš, Serbia | Creative Commons Licence: CC BY-NC-ND 


\section{INTRODUCTION}

Rarely does an issue in the area of corporate finance attracts so much continuous attention and interest as does the matter of mergers and acquisitions ("M\&As"). In both academic and business circles debates are constantly held on the underlying motives for such transactions and whether they are justified, whether the amounts paid are adequate, who wins and who loses and what information regarding a particular M\&A may be revealed from the response of the market prices to the M\&A announcement. A particularly interesting series of questions arise upon analysis of the phenomenon of information "leakage" into the market prior to the official M\&A announcement as well as whether the market perceives the price offered for the target's shares as realistic. However, the question of all questions is why the market is so skeptical and strict in anticipation of the successfulness of those transactions.

What is substantially typical of the largest number of M\&As is payment of an acquisition premium (the so-called bid premium), which is the difference between the price offered by the bidder and the currently trading price of the target's shares. The empirical research suggest that the average bid premium ranges between $20 \%$ and $40 \%$ (Goergen \& Renneboog, 2004). The premiums offered by bidder to take over control over the target significantly raise the market expectations and make the market more rigid in comparison to some other transaction types. In fact, when a bidder offers a price above the target's share price, the bidder must justify the premium paid through the post-transaction integration, through exceeding the market expectations and doing something that the target was unable to do on its own. This exclusively relates to the synergy effects. So, the market is strict and skeptical about M\&A transaction success, primarily because the investors are skeptical whether the bidder will be able to firstly conserve the value created within the target prior to the transaction, and on top of that, succeed in creating the expected synergy effects (Sirower \& Sahni, 2006).

Now that we have considered the main reasons for the market's caution about M\&A transactions, let us state here that different theories address different determinants of M\&A transaction successfulness. For instance, upon identification of determinants for the bid premiums in international M\&As, the classical M\&A theory focuses on the factors such as risk diversification, increased operational effectiveness and change in the market power. On the other hand, the neoclassical theory emphasizes changes in the shareholder rights and changes in the features of the corporate governance resulting from the bidder and the target operating in different institutional environments (Bhagat, Malhotra \& Zhu, 2011). Xie et al. (2017) find that "institutional and regulatory framework, tax provisions, economic performance, financial markets development, investor protection, geographical setting and cultural factors have differential effects on the inward and outward capital flows". Further, they find that "institutional dichotomous issues like the ruling political party influence, government intervention, higher levels of corruption, and erratic behavior of bureaucracy have detrimental effects on the completion likelihood of publicly announced acquisition transactions".

What makes the field of mergers and acquisitions dynamic and vibrant at all times is the fact that characteristics of these transactions are not universal and static but varying in terms of both space and time. The intention of this paper is to highlight the space and time dimension of M\&A transactions. 


\section{LITERATURE REVIEW}

Characteristics of M\&A transactions may vary depending on the economic and institutional environments in which the transactions are performed. Rossi and Volpin (2004) confirm that target companies operating in the United States realize statistically significantly higher abnormal returns against the comparable companies operating in other markets. In fact, it is identified that the average bid premium in the US-based transactions is by 7 percentage points higher than the premiums paid in the non-US transactions. Although it has been established that in the US-based M\&A transactions statistically significant synergy effects are realized, it turns out that those are not sufficient to account for the differences in bid premiums between the US entities and entities operating in other markets. This means that the explanation for bid premium differences ought to be sought in different legislation and different scope of shareholder rights which are closely related to stronger bargaining power.

The main distinction about the US market in comparison to the other countries is higher competition in the market for corporate control reflected in the higher volume of M\&A transactions and more diverse and potentially more efficient defense measures against hostile takeovers. M\&A activities are considerably higher in volume in the countries with better investor protection, which is regarded as the key prerequisite of an active market for corporate control (Rossi \& Volpin, 2004). The final conclusion hence could be that in the USA there is a higher level of protection of target shareholders than in the practices of other countries, which improves their bargaining power and enables higher bid premiums and the abnormal returns of the targets than those realized by the targets in other markets.

It is interesting that the conclusions reached are somewhat modified if the abnormal returns of the bidders are analyzed. Alexandridis et al. (2010) show that bidders operating in the markets of Continental Europe, Australia, Japan and other countries with relatively low competition in the market for corporate control realize significantly higher returns than the bidders operating in the USA, Canada, and the UK. This is in line with the thesis that high competition in the market for corporate control, although having a positive impact on the returns of the targets, may have negative ultimate implications on the returns of the bidders. In fact, the high competition levels in the market for corporate control causes bidders to increase gradually the bid premiums offered for target takeover, resulting in payment of excessive premiums, which are often not justified by commensurately higher synergy effects.

In order to measure the competition level in the market for corporate control Alexandridis et al. (2010) focus on listed target companies involved in the completed M\&A transactions in the specific year relative to the total number of listed companies operating in the market under analysis. The highest competition levels in the market for corporate control are recorded in the US, the UK and Canada since these are countries with the largest numbers of listed companies that are subject to control takeover in the specific year. The average bid premium values identified in those markets equal $45.79 \%, 42.02 \%$ and $37.01 \%$, respectively, whereas in the rest of the world the average bid premium recorded in the same period is merely $31.91 \%$. Moreover, the abnormal returns of the bidders operating in Europe (excluding the UK), Japan, the rest of Asia, Australia and Oceania, South Africa and Latin America are non-negative and statistically significantly higher than those of the bidders from the countries with the largest volume of M\&A transactions.

Ylmaz and Tanyeri (2016) find that, viewed on the global level, M\&A transactions create value with the cumulative average abnormal return of $1.7 \%$. When it comes to the 
differences in respect of three-day cumulative abnormal returns identified between the companies in developed countries and companies operating in developing countries, results are somewhat different from Alexandridis et al. (2010). In terms of the results relating to the returns realized by the target shareholders, there are no deviations from the above discussed results. The results show that CAR of the targets operating in developed countries equals $8.1 \%$, while that of the targets in developing countries is as low as $2.8 \%$. While the difference between CARs realized by the targets was anticipated, the research shows that returns realized by the bidder shareholders are also higher for companies operating in developed countries, although the difference is of a much less scale than the difference identified for the targets ' One of the explanations for the divergent results of the aforesaid two studies in terms of abnormal returns realized by the bidders is the use of different event windows for measurement of cumulative abnormal returns. Since the developing countries are characterized by a slower pace of the market adaptation to new information (lower market efficiency), the use of shorter event windows for CAR measurement might cause underestimation of the returns realized by the bidder shareholders upon transaction announcement. Relaying on this finding we are introducing time frame as one of the key features of our bid premium analysis.

With regard to the generation and distribution of the total gains realized in M\&A transactions, results of the sample studies encompassing international M\&As ought to be considered, especially those where companies operating in the countries with developed market economies were observed as bidders and companies operating in developing countries as targets. The results of related studies show that shareholders commonly realize positive combined returns in such transactions, whereby the gains are unevenly distributed in favor of the bidders (Bellotti \& Williams, 2008).

The increasing volume of international M\&As involving companies from developing countries as bidders made some researchers deal with the characteristics of such transactions in more detail. The highest growth in value of such transactions of as much as $392 \%$ was identified in the period from 2004 through 2008. In 2006 consulting firm BSG published a study demonstrating that 100 most successful companies from developing countries are constantly strengthening their global influence by increasing their presence in various industries, with such influence strengthening realized not exclusively through export as one of the possible channels, but rather through the ever growing volume of international M\&A transactions in which these companies appear as bidders (Bhagat \& Malhotra, 2011).

In general, the main drivers of the bidders from developing countries in targeting companies from the countries with developed market economies are classified into two major groups: (1) acquisition of strategically valuable resources such as technology, brand, managerial talent, distribution channels and natural resources and (2) avoidance of institutional restrictions existing in their countries of origin. These transactions create value on the average, where the cultural differences between the bidders and the targets pose the most significant barrier to value creation. In fact, in instances of international M\&As, the capacity to learn and the level of adaptability to a new cultural environment are crucial determinants of success. Realization of abnormal returns is in line with the so-called bootstrapping hypothesis assuming that bidders realize positive abnormal returns upon transaction announcement where the quality of the target's corporate governance system is on a higher level. It is assumed that, in such an instance, the bidder enters into the transaction, among other reasons, in order to adopt and implement the higher corporate governance 
quality standards the target has in place (Bhagat et al., 2011; De Buele and Sels, 2016, Li et al., 2016). Brock (2005) also finds that "the cultural match or mismatch between the parties in international M\&As shape their ability to successfully integrate and share resources, which in turn affects the ability to realize synergies".

Apart from institutional environment and economic development of M\&A transaction participants, payment method and motives for entering the deal are important bid premium determinants.

Numerous empirical studies investigating the impact of the selected payment method on the bid premium amounts and successfulness of M\&A transactions have not produced uniform conclusions. Great many studies conducted in the USA almost unanimously found that transactions entirely financed with shares result in negative returns and low performance to the bidders. On the other hand, studies conducted in Europe demonstrate that share-based financing of transactions may result in positive and sometimes statistically significant returns to the bidders. Similarly, certain authors claim that higher bid premiums positively correlate to the predominant cash payments (De La Bruslerie, 2013). Chatterjee and Kuenzi (2001) find that announcements of M\&A transactions involving bidders with surplus cash funds ought to bring about negative returns to the bidder shareholders. The payment method is frequently associated with the level of the shareholder legal protection. The probability of control takeover being financed entirely with cash declines as the level of the shareholder protection in the target's country of origin rises, which is explained by the fact that the high levels of shareholder protection increase the availability of financing with equity instruments. On the other hand, in the countries with low levels of shareholder protection, shareholders will be more willing to accept offers for payment in cash than share-based payment offers (Rossi \& Volpin, 2004).

Based on empirical and theoretical findings most commonly expressed motive for entering an M\&A transaction is creation of value, which may be realized through synergy effects arising from either the strategic fit (operating synergy) or through utilization of the financial benefits from the combination (financial synergy). Although both types of synergy effects are perceived as desirable, it is expected that an existing strategic fit between the bidder and the target increases readiness to pay higher bid premiums. In this regard, a number of empirical studies point out that takeovers realized within the same industries enable realization of higher returns than takeovers aimed at business portfolio diversification. Gupta and Misra (2007) and Golubov et al. (2016) actually confirm the economic theory views that expansion into the related industries enables more successful and faster activation of synergy effects in comparison to that of diversification.

In line with the previous research results that are presented in literature review section and our research objective the following hypotheses will be tested:

H1: There are statistically significant differences between bid premiums calculated 1 day and 30 days prior to/after the official M\&A announcement.

$\mathrm{H} 2$ : There are statistically significant differences in the bid premium amounts calculated prior to/after the official M\&A announcement depending on the institutional environment and economic development of the countries the participants in international M\&As come from.

H3: There are statistically significant differences in the bid premium amounts calculated prior to/after the official M\&A announcement depending on selected payment method.

H4: There are statistically significant differences in the bid premium amounts calculated prior to/after the official M\&A announcement depending on bidders act as strategic or financial buyers. 


\section{DATA AND SAMPLE}

In our research we create the sample by using the data from the Mergermarket database that includes mergers and acquisitions at the global economy level, with individual values of above USD 5 million. The analysis focuses on M\&A transactions announced in years 2015 and 2016, two periods relevant for examination of M\&A transactions characteristics and their behavior in regard to the condition and trends identified in the equity markets throughout the world. In fact, we identify three periods and regard them as three subsamples. The first, from January 1, 2015 to June 12, 2015 is a period prior to the general decline of the investor confidence (pre-confidence decline period). The second period, from June 12, 2015 to February 12, 2016, is a period when in almost all stock markets around the world the investor confidence decreased and the stock exchange indices recorded the most severe drops since the beginning of the global financial crisis in 2008 (confidence decline period). Such a trend was not identified in the USA only, where the most significant stock exchange indices recorded either no decline at all or decline much less severe than what happened in other markets. The third period, from February 12, 2016 to December 31, 2016, is a period of recovery and the investor confidence growth, i.e., a period of positive trends identified in all significant stock markets in the world (confidence recovery period).

As previously highlighted, in the second half of 2015 a drastic fall in share prices occurred in almost all large equity markets in the world as a result of a number of adverse events that took place in the global economy that year which had extremely negative effects on the global economic trends. One of the key circumstances that stopped the period of the steady increase in share prices in the global stock markets was the crash of the Chinese stock market that began in June 2015. From June 12 to August 24, 2015 the Shanghai Composite Index fell by $38 \%$ despite the efforts of the Chinese Government to prevent the negative tendencies in the economy. In addition, due to its default on liabilities toward IMF, on June 30, 2015 Greece declared bankruptcy. Among factors that led to the undoubtedly largest drop of the share prices after 2008, there were a plummet of oil prices, Chinese currency devaluation, decrease in investments in developing countries and investor expectations regarding the discontinuation of the expansionary monetary policy of the US Federal Reserve that would be expected to lead to a rise in general interest rate levels. Unlike 2015, which featured dropping share prices in the markets throughout the world, 2016 was a year of recovery and stabilization of the financial markets. As from February 2016, all the stock exchange indices recorded continuous rise apart from the short-term crash immediately before and after the UK referendum (Brexit). Increase in oil prices, recovery of the demand in the commodity and services markets, positive political trends in some countries and consistent policies of cheap money implemented by almost all central banks are some of the key factors that led to the recovery of the financial markets throughout the world and created positive investor expectations regarding the future performances of the major world economies.

The sample includes transactions announced during 2015 and 2016 and completed by the end of Q1 2017. Given that the focus of our analysis is on target share prices upon the $M \& A$ transaction announcement, the sample includes only transactions with targets in the form of public companies whose shares are publicly traded and whose prices are disclosed at the stock exchange. All transactions financed with debt instruments or hybrid equity instruments are excluded from the sample as well as all the transactions for which there is no full set of data required for the analysis. Out of the total number of the announced transactions, 834 transactions meet all the pre-defined criteria. 
Due to the specificities of operations of the financial institutions in comparison to the real sector companies, we exclude from the sample all transactions involving financial sector entities as targets. In addition, in order to reduce the influence of extreme bid premium values on the statistical testing results, the sample is winsorized by $1 \%$ at both the left and right distribution tail, separately for the bid premiums calculated prior and after the official merger announcement. Thus the final sample of $783 \mathrm{M} \& \mathrm{~A}$ transactions is obtained. Viewed per the three previously defined periods relevant for our research: in the first period 218 transactions meeting all of the required criteria were identified, 312 transactions were identified in the second period and $253 \mathrm{M} \& \mathrm{~A}$ transactions were identified in the third period.

Beside numerous approaches that may be used in examining the characteristics and successfulness of M\&A transactions, the methodological event study approach stands out in literature as particularly suitable (Bruner, 2002). Adnan and Hossain (2016) accentuate some benefits of event studies such as: "(1) short-term event study can screen the influence of outside factors to large extent; (2) data are easy to get publicly, allowing study on large sample; and (3) it is relatively objective public assessment". Upon definition of the methodology framework for the research our starting point relies on the powerful influence of the assumption of the semi-strong equity market efficiency on economic theory, whereby the existing share prices always incorporate and reflect all publicly available and relevant information. This hypothesis provides a theoretical foundation for the dominant implementation of the cumulative abnormal return methodology. Given that the contemporary empirical studies more and more often question whether the dominant use of CAR methodology is justified and that, according to some authors (Lim, Brooks \& Kim, 2008), the equity market efficiency form is not unalterable in time but may be changed from a pre-confidence decline, to a crisis and confidence recovery periods, in our research, although we remained within the event study field, we applied a slightly different approach. In this paper we examine the informative content of the bid premium and identify differences in the value of the bid premium depending on: (1) the observed timeframe; (3) characteristics of the market for corporate control in which the target operates and the degree of the economic development of the countries in which the transaction participants operate; and (4) selected payment method and motive for entering the transaction in regard to space and time dimensions of bid premiums.

\section{RESEARCH RESULTS}

\subsection{Bid premium behavior before and after the official $M \& A$ announcement}

When the sample is taken on the whole, the expected results are obtained showing that at the significance level of 5\% the average bid premium calculated 30 days prior to the official M\&A announcement is statistically significantly higher than the average bid premium calculated 1 day prior to the official transaction announcement. Such a result is in line with Keown and Pinkerton (1981) who find that "stock prices react to future mergers about one month before announcements". There are some authors such as Halpern (1973) and Mandelker (1974) who find "the price run-up may start several months before M\&A announcements" but in our paper we are not considering price run-ups that may occur more than one month before official M\&A announcement. While some researchers believe the run-up is caused by market anticipation or toehold acquisition, Tang et al. (2016) find "neither of the two is able to explain the target stock price run-up prior to M\&A announcements. Instead, variables that are associated with unreported insider trading are significantly associated with the run-up". 
Anyway, the use of bid premium calculated 1 day prior to the official transaction announcement for the purposes of analyzing the expected synergy effects and abnormal returns upon transaction announcement could lead to their inadequate evaluation.

If, on the other hand, testing is performed on each individual sub-sample defined, the results obtained are not uniform. In the confidence decline and confidence recovery period, the results arrived at, match the results obtained for the entire sample. However, in the period preceding the plummet of the share prices in almost all global stock markets (confidence pre-decline period), the results show that there is no statistically significant difference between the bid premiums calculated 30 days and 1 day prior the official merger announcement. For the sake of consistency, we elected to use the bid premium calculated 30 days prior to the official merger announcement in each of the three observed periods for the purposes of examining the bid premium informative content.

The bid premium calculated subsequent to the official M\&A announcement is used as a measure of the market response to the information reaching the market with regard to the transaction announcement. If the bidder appropriately measured the expected benefits from the transaction and defined the appropriate bid premium amount accordingly, and if, additionally, there is no uncertainty in respect of the transaction completion at the price defined in the offer, the market ought to equal the target share price to the share price defined in the offer. Statistically, this would mean that the bid premium calculated after the official M\&A announcement should not be statistically significantly different from zero.

We first test whether there is a statistically significant difference between the values of the bid premiums calculated 1 day and 30 days after the official M\&A announcement. Thereby we want to investigate whether the character of the market response to the transaction announcement changes with the passage of time and whether the market changes its initial "attitude" regarding the justification of the price offered in a particular transaction. Testing is first conducted on the entire sample and thereafter on each of the three sub-samples. In both instances identical results are obtained - there is no statistically significant difference between the amounts of 1-day and 30-day post announcement bid premiums. Naturally, this still tells little about what attitude the market assumed or whether the attitude changes over a period longer than a month following the official transaction announcement. The results obtained are provided in table 1 .

Table 1 Bid premium trends prior and after to transaction announcement

\begin{tabular}{lcccc}
\hline Paired Samples Test & Mean & Std. Deviation & T statistic & Sig. (2-tailed) \\
\hline For the entire sample & & & & \\
$\quad$ Bid Premia Share Price -1, -30 & -0.05684 & 0.31190 & -5.100 & 0.000 \\
$\quad$ Bid Premia Share Price +1, +30 & -0.01134 & 0.35101 & -0.904 & 0.366 \\
\hline $\begin{array}{c}\text { Pre-confidence decline period } \\
\quad \text { Bid Premia Share Price -1, -30 }\end{array}$ & -0.05280 & 0.47005 & -1.658 & 0.099 \\
$\quad$ Bid Premia Share Price $+1,+30$ & -0.00646 & 0.12170 & -0.784 & 0.434 \\
\hline Crisis period & & & \\
$\quad$ Bid Premia Share Price -1, -30 & -0.03750 & 0.24832 & -2.667 & 0.008 \\
$\quad$ Bid Premia Share Price +1, +30 & -0.00595 & 0.13537 & -0.776 & 0.438 \\
\hline Confidence recovery period & & & & \\
$\quad$ Bid Premia Share Price -1, -30 & -0.08418 & 0.18519 & -7.230 & 0.000 \\
$\quad$ Bid Premia Share Price $+1,+30$ & -0.02220 & 0.58890 & -0.600 & 0.549 \\
\hline
\end{tabular}


In order to examine the character of the market response to the transaction announcement we test whether the average bid premiums calculated at +1 and +30 points in time statistically significantly differ from zero, which would mean the market's perception of the prices defined in the offer is unjustifiably high, i.e., that the bid premium value is above its realistic value (results are presented in table 2). When viewed per sub-sample, the testing results on the first two periods are identical, the average bid premiums at +1 and +30 points in time are statistically significantly higher than zero. On one end, these results may be interpreted in the context of the market's inability to incorporate the new information in the target share prices in the relatively short period of 30 days only. On the other, the explanation may be found in the fact that, despite the adequate and timely market response, the target share prices do not reach the level of the prices offered because the bidder offered an unjustifiably high premium in a particular transaction or there is uncertainty in respect of the transaction completion at the price defined in the offer. We decided to use the bid premium calculated 30 days after the transaction for measurement of the market response to the merger announcement. The main reason for this choice was the fact that we used the bid premium calculated 30 days before the official transaction announcement to measure the expected synergy effects on the bid premium amount.

Table 2 Bid premium and the market response to the transaction announcement

\begin{tabular}{lcccc}
\hline One Sample Statistics $(\mathrm{t}=0)$ & Mean & Std. Deviation & T statistic & Sig. (2-tailed) \\
\hline For the entire sample & & & & \\
$\quad$ Bid Premia Share Price +1 & 0.0461 & 0.18289 & 7.051 & 0.000 \\
$\quad$ Bid Premia Share Price +30 & 0.0574 & 0.38695 & 4.153 & 0.000 \\
\hline $\begin{array}{l}\text { Pre-confidence decline period } \\
\quad \text { Bid Premia Share Price }+1\end{array}$ & 0.0344 & 0.18680 & 2.722 & 0.007 \\
$\quad$ Bid Premia Share Price +30 & 0.0409 & 0.24718 & 2.443 & 0.015 \\
\hline Crisis period & & & & \\
$\quad$ Bid Premia Share Price +1 & 0.0608 & 0.17368 & 6.179 & 0.000 \\
$\quad$ Bid Premia Share Price +30 & 0.0667 & 0.19295 & 6.106 & 0.000 \\
\hline Confidence recovery period & & & & \\
$\quad$ Bid Premia Share Price +1 & 0.0380 & 0.18992 & 3.186 & 0.002 \\
$\quad$ Bid Premia Share Price +30 & 0.0602 & 0.60476 & 1.584 & 0.114 \\
\hline
\end{tabular}

Source: Authors' calculation

\subsection{Bid premium - institutional environment and the degree of the economic development of the countries in which the transaction participants operate}

Due to complexity of the international M\&As, we decide to focus on this particular type of transactions and investigate if there are any differences in the bid premium amounts depending on the economic development of the countries of origins of the transaction participants. To this end, based on the United Nations' classification we made four subsamples: sub-sample one, comprised of transactions involving both bidders and targets from developed countries; sub-sample two, comprised of transactions involving both bidders and targets from developing countries; sub-sample three with bidders from developed countries and targets from developing countries; and sub-sample four with bidders from developing countries and targets from developed countries.

The testing results demonstrate there are statistically significant differences in the bid premium amounts calculated prior to the official merger announcement depending on the 
level of economic development of the countries the participants in international M\&As come from. It is interesting that the highest average bid premium of as much as $37 \%$ was identified within the subsample of transactions involving bidders from developing countries and targets from developed economies. Such a high average bid premium amount is in line with the previously stated theoretical assumptions and empirical evidence from ( $\mathrm{Li}$ et al., 2016; De Buele and Sels, 2016; Bhagat et al., 2011). Almost identical average bid premium of $36.7 \%$ was identified, as expected, in the transactions where both bidders and targets come from developed countries. Somewhat lower average bid premium (33\%) was recorded in the transactions involving bidders from developed and targets from developing countries, which may be due to lower synergy effects expected in such transactions and weaker bargaining power of the target shareholders. Definitely the lowest average bid premiums of only $18 \%$ were recorded in transactions involving both the bidder and the targets from developing countries. The average bid premiums presented above range between $18 \%$ and $37 \%$ which is almost in line with Goergen and Renneboog (2004) 20\% - 40\% bid premium range.

Next we test if the average bid premiums recorded after the official M\&A announcement are statistically significantly different from zero. We are interested in the differences, if any, in the market responses to the transaction announcement depending on the economic development of the country. The testing results show that, in all instances save the one where both bidders and targets operate in the developing countries, the bid premiums calculated upon the transaction announcement are statistically significantly above zero. The highest average bid premium $(9 \%)$ was identified in the transactions involving bidders from developing and targets from developed economies. As it was previously found that the highest takeover premiums are offered in transactions of this type, the question is whether bidders from developing countries overestimate benefits from penetration in the developed markets and/or have insufficiently strong bargaining power in such circumstances, which all together results in unjustifiably high bid premiums offered and consequent overpayment of transactions. On the other hand, insufficiently positive market response to the announcement of this type of transactions may be a consequence of the market's skepticism about success of the post-merger integration due to cultural differences and insufficient absorptive capacities of the bidders. In transactions involving both bidders and targets from developed countries, the identified overpayment may be due to the high competition levels in the market for corporate control Alexandridis et al. (2010), while the transactions involving bidders from developed and targets from developing countries the high bid premiums at +30 may be caused by both overpayment and the fact that the developing countries are characterized by a slower pace of adaptation to new information coming to the market (lower market efficiency). On the other end, the average bid premium +30 in transactions involving both the bidders and the targets from developing countries is identified as not statistically significantly different from zero, which leads to a conclusion on adequately measured prices offered for takeover of the target shares. It is particularly interesting that in this group of transactions we find a negative average bid premium at +30 point in time ($1.4 \%$ ), which mean that these transactions are not only not overpaid but that the premiums offered are too low which is in line with Ang and Ismail (2015). 
Table 3 Bid premium in regard to economic development of the paticipants' countries

\begin{tabular}{lcccc}
\hline ANOVA & F statistic & Sig. (2-tailed) \\
\hline For the entire sample & & & \\
Bid Premia Share Price -30 & 9.347 & 0.000 \\
Bid Premia Share Price +30 & 1.545 & 0.201 & \\
\hline & Mean & Std. & T statistic & $\begin{array}{c}\text { Sig. } \\
\text { (2-tailed) }\end{array}$ \\
\hline One Sample Statistics (t=0) & & & & \\
\hline For the entire sample & & & & \\
\hline Bid Premia Share Price +30 (segment 1) & 0.0606 & 0.41491 & 3.470 & 0.001 \\
Bid Premia Share Price +30 (segment 2) & 0.0114 & 0.02329 & 0.489 & 0.625 \\
Bid Premia Share Price +30 (segment 3) & 0.0499 & 0.08002 & 3.414 & 0.002 \\
Bid Premia Share Price +30 (segment 4) & 0.1434 & 0.42288 & 2.492 & 0.016 \\
\hline
\end{tabular}

Source: Authors' calculation

\subsection{Bid premium - payment methods and motives for M\&A transactions}

We first test whether there are statistically significant differences in the bid premium amounts calculated prior to the official transaction announcement depending on whether the transaction is financed with cash, shares or a combination thereof. The results show that there are statistically significant differences in the bid premium amounts per payment method, where the highest average bid premium is identified in cash-financed transactions, and the lowest in entirely share-financed ones. This result correlates to Goergen and Renneboog (2004) who claim that higher bid premiums positively correlate to the predominant cash payments.

However, the testing results per sub-sample suggest that statistically significant differences in the bid premium amounts per selected payment method arise exclusively in the crisis period, while no such differences are identified in the pre-confidence decline and confidence recovery periods. The stronghold for this result we find in the different level of M\&A participants' legal protection relative to general market trends. Shah and Arora (2014) finds that the level of investor protection is lessened in the period of crisis. On the other hand, analysing the market response to the transaction announcement, the results obtained at the entire sample level show that the average bid premium calculated 30 days after the transaction announcement is statistically significantly above zero for each of the three payment methods. However, at the level of individual period, the results were heterogeneous. In fact, the results demonstrate that the prices offered by bidders in cash-financed transactions are perceived as adequate on the average in both the preconfidence decline period and confidence recovery period, while in the crisis period such prices are perceived as overestimated. However, the results suggest that, in instances of share-financed transactions and those financed with cash and shares combined to some extent, the market perceives the prices offered as unrealistically high, irrespective of the current situation in the equity market which is in line with Gupta and Misra (2007). Here we need to underline another important finding, that in the crisis period, target share prices remain below the price offered after the transaction announcement irrespective of the selected payment method. Among other things, this may be a consequence of the market's higher skepticism during the crisis period as to whether the transactions announced will be completed. 
Table 4 Bid premium in regard to selected payment method

\begin{tabular}{|c|c|c|c|c|c|}
\hline Descriptives / ANOVA & Mean-cash & $\begin{array}{l}\text { Mean- } \\
\text { equity }\end{array}$ & $\begin{array}{l}\text { Mean- } \\
\text { mixed }\end{array}$ & F statistic & $\begin{array}{c}\text { Sig. } \\
\text { (2-tailed) }\end{array}$ \\
\hline \multicolumn{6}{|l|}{ For the entire sample } \\
\hline Bid Premia Share Price -30 & 0.3570 & 0.2655 & 0.2911 & 3.968 & 0.019 \\
\hline Bid Premia Share Price +30 & 0.0408 & 0.1008 & 0.0963 & 1.801 & 0.166 \\
\hline \multicolumn{6}{|l|}{ Pre-confidence decline period } \\
\hline Bid Premia Share Price -30 & 0.3079 & 0.2335 & 0.2877 & 0.652 & 0.522 \\
\hline Bid Premia Share Price +30 & 0.0187 & 0.0842 & 0.787 & 1.619 & 0.200 \\
\hline \multicolumn{6}{|l|}{ Crisis period } \\
\hline Bid Premia Share Price -30 & 0.3675 & 0.2648 & 0.2465 & 2.973 & 0.053 \\
\hline Bid Premia Share Price +30 & 0.0449 & 0.1414 & 0.1148 & 6.066 & 0.003 \\
\hline \multicolumn{6}{|l|}{ Confidence recovery period } \\
\hline Bid Premia Share Price -30 & 0.3812 & 0.2966 & 0.3640 & 0.824 & 0.440 \\
\hline Bid Premia Share Price +30 & 0.0525 & 0.0741 & 0.0951 & 0.067 & 0.935 \\
\hline \multicolumn{2}{|l|}{ One Sample Statistics $(\mathrm{t}=0)$} & \multicolumn{2}{|r|}{ T statistic } & \multicolumn{2}{|c|}{ Sig. (2-tailed) } \\
\hline \multicolumn{6}{|l|}{ For the entire sample } \\
\hline \multicolumn{2}{|c|}{ Bid Premia Share Price +30 (Cash) } & \multicolumn{2}{|r|}{2.210} & \multicolumn{2}{|c|}{0.028} \\
\hline \multicolumn{2}{|c|}{ Bid Premia Share Price +30 (Equity) } & \multicolumn{2}{|r|}{4.460} & \multicolumn{2}{|c|}{0.000} \\
\hline Bid Premia Share Price +3 & Mixed) & & 6.359 & \multicolumn{2}{|c|}{0.000} \\
\hline \multicolumn{6}{|l|}{ Pre-confidence decline period } \\
\hline \multicolumn{2}{|c|}{ Bid Premia Share Price +30 (Cash) } & \multicolumn{2}{|r|}{0.840} & \multicolumn{2}{|c|}{0.402} \\
\hline \multicolumn{2}{|c|}{ Bid Premia Share Price +30 (Equity) } & \multicolumn{2}{|r|}{2.012} & \multicolumn{2}{|c|}{0.051} \\
\hline \multicolumn{2}{|c|}{ Bid Premia Share Price +30 (Mixed) } & \multicolumn{2}{|r|}{3.646} & \multicolumn{2}{|c|}{0.001} \\
\hline \multicolumn{6}{|l|}{ Crisis period } \\
\hline \multicolumn{2}{|c|}{ Bid Premia Share Price +30 (Cash) } & \multicolumn{2}{|r|}{3.612} & \multicolumn{2}{|c|}{0.000} \\
\hline \multicolumn{2}{|c|}{ Bid Premia Share Price +30 (Equity) } & \multicolumn{2}{|r|}{4.132} & & \\
\hline Bid Premia Share Price +3 & Mixed) & & 4.754 & & \\
\hline Confidence recovery period & & & & & \\
\hline Bid Premia Share Price +3 & Cash) & & 1.042 & & \\
\hline Bid Premia Share Price +3 & Equity) & & 1.779 & & \\
\hline Bid Premia Share Price +3 & Mixed) & & 2.576 & & \\
\hline
\end{tabular}

Source: Authors' calculation

In the next instance, we focus on the motive for entering the M\&A transactions as one of the key determinants of bid premium value. We test the hypothesis that bid premiums calculated prior to the official M\&A announcement involving strategic buyers as bidders are statistically significantly higher than such transactions with financial buyers as bidders. The hypothesis is confirmed at the level of the entire sample (all three periods jointly). Such a result unambiguously suggests that acquisition strategy (expansion or diversification) has an impact on the bid premium amount as well as on the willingness to offer higher premiums. These higher premiums should be justified by the "core business" strengthening, strategic fit activation and gaining or increasing of the competitive advantage in the process of post-merger integration.

When hypothesis is tested on the sub-samples of pre-confidence decline and confidence recovery periods, the results obtained are identical to those for the entire sample. However, when we observe transactions performed in the crisis period, we come to a conclusion that there 
is no statistically significant difference between the bid premiums calculated prior to the M\&A announcement in instances of strategic buyers as bidders and those of financial buyers as bidders. This indicates that in periods featuring negative trends in the stock markets the values of operating and financial synergies become convergent. A relevant study of J.P. Morgan that was focused on the research of M\&A characteristics in the crisis periods found that, even in such circumstances, due to a more difficult access to the stock market and due to higher capital costs, companies much more turn to achievement of financial synergies (J.P.Morgan, 2009).

When it comes to the market response to the transaction announcement depending on the primary acquisition motive, viewed at the entire sample level, the market makes no distinction between strategic and financial buyers and perceives both types of bidders as offering unjustifiably high bid premiums. However, somewhat different conclusions imposed on us upon separate testing of the sub-samples. In similarity to the analysis of the impact of the payment method, here as well the market sees prices offered by bidders as unrealistically high in the crisis period, irrespective of the motive for entering the transaction. This may be attributable to the higher market skepticism as to whether the announced transactions will be realized. Moreover, upon respective analyses of the preconfidence decline period and the recovery period, we observe that the +30 bid premium was statistically significantly above zero only when strategic buyers appeared as bidders. On the other hand, in transactions involving financial buyers as bidders, the bid premium values did not differ statistically significantly from zero. Therefore, we may ultimately

Table 5 Bid premium in regard to payment method and the motive for entering the transaction

\begin{tabular}{lcccc}
\hline Independent Samples Test & $\begin{array}{c}\text { Mean- } \\
\text { strategic }\end{array}$ & $\begin{array}{c}\text { Mean- } \\
\text { financial }\end{array}$ & T statistic & Sig. (2-tailed) \\
\hline For the entire sample & & & & \\
$\quad$ Bid Premia Share Price -30 & 0.3532 & 0.2632 & 3.255 & 0.001 \\
$\quad$ Bid Premia Share Price +30 & 0.0663 & 0.0246 & 2.026 & 0.043 \\
\hline $\begin{array}{l}\text { Pre-confidence decline period } \\
\text { Bid Premia Share Price -30 }\end{array}$ & 0.3103 & 0.2026 & 2.356 & 0.021 \\
$\quad$ Bid Premia Share Price +30 & 0.0510 & -0.0054 & 1.292 & 0.198 \\
\hline Crisis period & & & & \\
$\quad$ Bid Premia Share Price -30 & 0.3517 & 0.2857 & 1.303 & 0.194 \\
$\quad$ Bid Premia Share Price +30 & 0.0692 & 0.0565 & 0.465 & 0.643 \\
\hline Confidence recovery period & & & & \\
$\quad$ Bid Premia Share Price -30 & 0.3961 & 0.2780 & 2.167 & 0.031 \\
$\quad$ Bid Premia Share Price +30 & 0.0769 & 0.0120 & 0.745 & 0.457 \\
\hline
\end{tabular}

\begin{tabular}{|c|c|c|}
\hline One Sample Statistics $(\mathrm{t}=0)$ & T statistic & Sig. (2-tailed) \\
\hline \multicolumn{3}{|l|}{ For the entire sample } \\
\hline Bid Premia Share Price +30 (Strategic) & 3.836 & 0.000 \\
\hline Bid Premia Share Price +30 (Financial) & 2.192 & 0.030 \\
\hline \multicolumn{3}{|l|}{ Pre-confidence decline period } \\
\hline Bid Premia Share Price +30 (Strategic) & 2.545 & 0.012 \\
\hline Bid Premia Share Price +30 (Financial) & -0.339 & 0.737 \\
\hline \multicolumn{3}{|l|}{ Crisis period } \\
\hline Bid Premia Share Price +30 (Strategic) & 5.755 & 0.000 \\
\hline Bid Premia Share Price +30 (Financial) & 2.171 & 0.034 \\
\hline \multicolumn{3}{|l|}{ Confidence recovery period } \\
\hline Bid Premia Share Price +30 (Strategic) & 1.507 & 0.134 \\
\hline Bid Premia Share Price +30 (Financial) & 1.234 & 0.221 \\
\hline
\end{tabular}

Source: Authors' calculation 
conclude that the strategically oriented bidders overestimate the expected synergy effects on the average and offer unrealistically high premiums irrespective of the current stock market trends, while bidders focused on financial synergies on the average, save in the crisis periods, adequately value the premiums they offer for takeover of control.

\section{CONCLUSION}

The research demonstrates that in the crisis and confidence recovery periods there are phenomena of the information "leakage" and insider trading in the market, which cause underestimations of the bid premium amounts calculated immediately before the official transaction announcement. However, analysis of the transactions announced in the preconfidence decline period show that there is no statistically significant difference between the bid premium calculated 30 days and those calculated 1 day before the official transaction announcement. Upon analysis of the market response to the official transaction announcement, the conclusion arrived at suggests that, irrespective of the current stock market trends, the target shares do not reach the price defined by the takeover bid. On one end, these results may be interpreted in the context of the market's inability to incorporate the new information in the target share prices in the relatively short period of 30 days only. On the other, the explanation may be found in the fact that, despite the adequate and timely market response, the target share prices do not reach the level of the prices offered because the bidder offered an unjustifiably high premium in a particular transaction. Deepening our analysis, rather interestingly, we identify that the highest average bid premium was recorded in transactions involving bidders from developing countries and targets from developed economies. On the other hand, by examining the bid premium calculated at the +30 point in time, we identify a positive correlation with the competition level in the market for corporate control, as well as a strong influence of bidder and target country economic development on the determination of the bid premium amount. Additionally, we focus on and selected payment method as well as strategic vs. financial takeovers and find evidence of different behaviors in respect to the market conditions (different points in time) and institutional environments (space dimension) where M\&A transactions are being conducted.

Findings from our study mostly correlate to the empirical research body in the area of mergers and acquisitions. As an extension of this analysis, on one hand, a wider time frame ought to be introduced to verify the implications of the time frame proposition. On the other hand, a broader approach on transaction participants, especially on the bidders' side would deepen the scope and quality of the research. The broader perspective would be expected to provide more evidence on the bid premium determinants and the willingness of the bidders to pay in an M\&A transaction. 


\section{REFERENCES}

Alexandridis, G., Petmezas, D., \& Travlos, N.G. (2010). Gains from Mergers and Acquisitions Around the World: New Evidence. Financial Management, 39 (4), 1671 - 1695.

Ang, J.S. \& Ismail A.K. (2015). What premiums do target shareholders expect? Explaining negative returns upon offer announcements. Journal of Corporate Finance, 30, 245 - 256. http://dx.doi.org/10.1016/ j.jcorpfin.2014.12.015

Bellotti, X.A. \& Williams, J.M. (2008). Do Win-Win Outcomes Exist? A Study of Cross-Border M\&A Transactions in Emerging Markets. Comparative Economic Studies, 50 (2), 274 - 296.

Bhagat, S., Malhotra, S. \& Zhu P.C. (2011). Emerging country cross-border acquisitions: Characteristics, acquirer returns and cross-sectional determinants. Emerging Markets Review, 12 (2011), 250 - 271.

Brock, D.M. 2005. Multinational acquisition integration: the role of national culture in creating synergies. International Business Review, 14 (3), 269 - 288.

Bruner, R.F. (2002). Does M\&A Pay? A Survey of Evidence for the Decision-Maker. Journal of Applied Finance, 12 (1), $48-68$.

Chatterjee, R. \& Kuenzi, A. (2001). Mergers and Acquisitions: The Influence of Methods of Payment on Bidder's Share Price, Cambridge, The Judge Institute of Management Studies, Working Paper 6/2001.

De Beule, F. \& Sels, A. (2016). Do innovative emerging market cross-border acquirers create more shareholder value? Evidence from India. International Business Review, 25 (2), 604 - 617.

De La Bruslerie, H. (2013). Crossing Takeover Premiums and Mix of Payment: Empirical Test of Contractual Setting in M\&A Transactions. Journal of Banking \& Finance, 37 (6), 2106-2123.

Goergen, M. \& Renneboog, L. (2004). Shareholder Wealth Effects of European Domestic and Cross-border Takeover Bids. European Financial Management, 10, 9 - 45.

Golubov, A., Petmezas, D. \& Travlos, N.G. (2016). Do Stock-Financed Acquisitions Destroy Value? New Methods and Evidence. Review of Finance, 20 (1), 161 - 200.

Gupta, A. \& Misra, L. (2007). Deal Size, Bid premium, and Gains in Bank Mergers: The Impact of Managerial Motivations. The Financial Review, 42 (3), 373 - 400

Halpern, P. (1973). Empirical Estimates of the Amount and Distribution of Gains to Companies in Mergers. The Journal of Business. 46 (4), 554 - 575.

J.P. Morgan. (2009). A shifting landscape for synergies: How financial considerations are affecting value creation in mergers and acquisitions? Available at https://www.jpmorgan.com/jpmpdf/1320675767611.pdf

Keown, A. \& Pinkerton J. (1981). Merger Announcements and Insider Trading Activity: An Empirical Investigation. The Journal of Finance, 36 (4), 855 - 869.

Li, J., Li, P. \& Wang, B. (2016). Do cross-border acquisitions create value? Evidence from overseas acquisitions by Chinese firms. International Business Review, 25 (2), 471 - 483.

Lim, K.P., Brooks, R.D. \& Kim, J.H. (2008). Financial crisis and stock market efficiency: Empirical evidence from Asian countries. International Review of Financial Analysis, 17 (3), 571 - 591.

Mandelker, G. (1974). Risk and return: The case of merging firms. Journal of Financial Economics, 1 (4), 303 - 335.

Rossi, S. \& Volpin, P. (2004). Cross-Country Determinants of Mergers and Acquisitions. Journal of Financial Economics, 74 (2), 277-304.

Shah, P. \& Arora, P. (2014). M\&A Announcements and Their Effect on Return to Shareholders: An Event Study. Accounting and Finance Research, 3 (2), 170 - 190.

Sirower, M. \& Sahni, S. (2006). Avoiding the "Synergy Trap": Practical Guidance on M\&A Decisions for CEOs and Board. Journal of Applied Corporate Finance, 18 (3), 83 - 95.

Tang, Z. \& Xu, X. (2016). What Causes the Target Stock Price Run-Up Prior to M\&A Announcements?. Journal of Accounting and Finance, 16 (6), 106 - 120.

Xie, E., Reddy, K.S. \& Liang, J. (2017) Country-specific determinants of cross-border mergers and acquisitions: A comprehensive review and future research directions. Journal of World Business, 52 (2), $127-183$

Yilmaz, I.S. \& Tanyeri, B. (2016). Global Merger and Acquisition (M\&A) activity: 1992 - 2011. Finance Research Letters, 17 (2016), 110 - 117. 


\section{ZAŠTO PLATITI VIŠE - DETERMINANTE VREDNOSTI PREMIJA ZA PREUZIMANJE U MERDŽERIMA I AKVIZICIJAMA NA SVETSKOM NIVOU}

Merdžeri $i$ akvizicije predstavljaju jednu od najdinamičnijih oblasti u svetu korporativnih finansija.Uspeh ovih izuzetno kompleksnih transakcija može varirati u zavisnosti od ekonomskog $i$ institucionalnog okruženja u kojima se transakcije realizuju $U$ ovom radu se analizira informacioni sadržaj premija za preuzimanje kao i razlike koje se javljaju u njihovim vrednostima u zavisnosti od: (1) posmatranog vremenskog okvira pre i nakon $M \& A$ transakcije (2) trenutnih kretanja na tržištima kapitala (3) karakteristika institucionalnog okruženja i nivoa ekonomske razvijenosti zemalja iz kojih učesnici u transakcijama potiču i (4) izabranog metoda plaćanja i motiva za ulazak u transakciju. Na uzorku od 783 merdžera i akvizicija realizovanih na globalnom nivou potvrđeno je da se visina premije za preuzimanje razlikuje u zavisnoti od posmatranog vremenskog okvira uz prisustvo fenomena "curenja" informacija kao i uz prisutno neprilagođavanja cena u ponudi cenama akcija targeta u vremenskom okviru +30 . Vrednost premije za preuzimanje pod jakim je uticajem karakteristika instiucionalnog okruženja i nivoa ekonomskog razvoja zemalja iz kojih potiču preduzeća bidderi i targeti kao i pod uticajem metoda plaćanja i motiva za ulazak u M\&A transakcije. U radu je pokazano da se rezultati često razlikuju u zavisnosti od toga da li su u analizu uključeni dominantni trendovi na najznačajnijim tržištima kapitala.

Ključne reči: merdžeri, akvizicije, premija za preuzimanje, tržište za korporativnu kontrolu, institucionalno okruženje, metode plaćanja 